\title{
Antenatal Thymosin $\beta 4$ : a New Tool for Accelerating Fetal Development in Preterms? Thymosin Beta-4: a Breakthrough in the "Physiological" Regenerative Medicine in Preterm Newborns
}

\author{
Massimo Castagnola ${ }^{1}(\mathbb{D})$, Giacomo Cao ${ }^{2(\mathbb{D})}$, Goce Kalcev ${ }^{3, *}{ }^{*}$, Germano Orrù ${ }^{4} \mathbb{D}$, Vassilios Fanos ${ }^{5(\mathbb{D})}$, \\ Gavino Faa ${ }^{6,7(\mathbb{D})}$, Mauro Giovanni Carta ${ }^{8(\mathbb{D})}$
}

1 Laboratory of Proteomics, the European Center for Brain Research. IRCCS Fondazione Santa Lucia, Rome, Italy; massimo.castagnola@icrm.cnr.it (M.C.);

2 Department of Mechanical Energy, Chemistry and Materials, University of Cagliari, Cagliari, Italy; giacomo.cao@dimcm.unica.it (G.C.);

3 International Ph.D. in Innovation Sciences and Technologies, University of Cagliari, Italy; gocekalcev@yahoo.com (G.K.);

4 Department of Surgical Sciences, University of Cagliari, Italy; gerorru@ gmail.com (G.O.);

5 Neonatal Intensive Care Unit, Department of Surgical Sciences, University of Cagliari, Cagliari, Italy; vafanos@jpnim.com (V.F.);

6 Division of Pathology, Department of Medical Sciences and Public Health, University of Cagliari, AOU of Cagliari, Cagliari, Italy; gavinofaa@gmail.com (G.F.);

7 Adjunct Professor of Pathology, Department of Biology, College of Science and Technology, Temple University, Philadelphia, PA, USA; gavinofaa@gmail.com (G.F.);

8 Department of Medical Sciences and Public Health, University of Cagliari, Italy; mgcarta@tiscali.it (M.G.K.);

* Correspondence: gocekalcev@yahoo.com (G.K.);

Received: 21.01.2021; Revised: 21.02.2021; Accepted: 25.02.2021; Published: 1.03.2021

Abstract: To prevent the health risks related to prematurity, multiple drugs have been introduced in clinical practice in recent years. This paper focuses on a new "physiological" regenerative approach to be started in the perinatal period, particularly on very low birth weight preterm infants. This new preventive approach underlined the necessity to start regenerative medicine very early after birth, a period in which kidney, brain, pancreas, and lung stem cells maintain their proliferative and differentiating abilities. Among the multiple factors proposed in the literature as potential growth promoters for preterm neonates, thymosin beta-4 (T $\beta 4)$ has been indicated as one of the most important candidates for regenerative medicine.

Keywords: regenerative medicine; preterm birth; thymosin beta-4 (T $\beta 4)$.

(C) 2021 by the authors. This article is an open-access article distributed under the terms and conditions of the Creative Commons Attribution (CC BY) license (https://creativecommons.org/licenses/by/4.0/).

\section{Introduction}

Preterm birth is a major challenge for most health care systems worldwide, with most perinatal deaths occurring in preterm infants [1]. Preterm delivery represents a risk factor not restricted to the newborn's survival, is associated with neurological impairment and disability occurring later in life [2-4]. Multiple drugs have been introduced in clinical practice in recent years to prevent the health risks related to prematurity. Among them, antenatal administration of corticosteroids to pregnant women with the preterm birth threat has been shown to accelerate lung maturation, allowing a better postnatal survival rate in preterm newborns $[5,6]$. Further 
studies have shown that antenatal corticosteroids represent the most important available tool to decrease the insurgence and severity of respiratory distress syndrome and mortality from premature birth $[7,8]$. The limit of corticosteroid treatment is linked to their ability to accelerate lung maturation exclusively, whereas prematurity is associated with delayed development of the whole human body. Among the conditions influencing brain and kidney development in neonates, premature birth represents one of the most important factors [9-11]. Nephrogenesis halts few weeks after birth, with the disappearance of multipotent stem/progenitor cells of the metanephric mesenchyme and the process blocks mesenchymal-to-epithelial transition that originates new nephrons [12-15]. Consequently, preterm infants are characterized by a much lower nephron burden than at-term newborns $[16,17]$. A low nephron number at birth may have significant consequences later in life, given that subjects with few nephrons should be considered at risk of developing kidney insufficiency in childhood and adulthood [18, 19]. Another organ particularly susceptible to the consequences of prematurity is the brain, whose development may be altered by preterm birth [20,21].

\section{Alterations in neuronal brain connectivity}

Alterations in neuronal brain connectivity and low neurons number caused by preterm birth can predispose to impaired cognitive performance and severe neurological and psychiatric disorders [22-27]. Preterm-born children showed perinatal neurodevelopmental insults in neurogenesis and impairment in neuronal migrations [28] as those hypothesized in the neurodevelopmental theory of schizophrenia [29]. In fact, preterm delivery may be a codeterminant of the risk of nonaffective psychosis in adulthood [30].

Taking all these data together, an important challenge is facing gynecologists and neonatologists: how to improve organ development in preterm infants to avoid the consequences due to the scarcity of well-developed cells in the various organs?

\section{New "physiological" regenerative approach}

To answer this question, some years ago, a new "physiological" regenerative approach to be started in the perinatal period was hypothesized, particularly focused on very low birth weight preterm infants [31]. The relevance of this hypothesis was the original timing of the regenerative approach. Contrary to the vast majority of regenerative projects, focused on organs affected by severe pathological changes, this new preventive approach underlined the necessity to start the regenerative medicine very early after birth, a period in which kidney, brain, pancreas, and lung stem cells maintain their proliferative and differentiating abilities. The abundance of progenitor stem cells in the preterm kidney represents an optimal target for starting a regenerative medicine immediately after birth [32]. This peculiar type of regenerative medicine was defined as "physiological" since it was considered a substitutive of human organs' physiological development interrupted by preterm delivery. In the following years, the neurodegenerative approach has had a recent impetuous development [33, 34].

\section{Thymosin beta-4 (Tß4)}

Among the multiple factors proposed in the literature as potential growth promoters for preterm neonates, thymosin beta-4 (T $\beta 4)$ has been indicated as one of the most important candidates for regenerative medicine [35]. T $\beta 4$ is a member of thymosins, a small peptide family is expressed in most human cells [36]. Goldstein AL first described thymosins in 1966 
as peptides purified from the calf thymus [37]. T $\beta 4$ is detectable in all the cells, tissues, and bodily fluids of humans. The best-known function of T $\beta 4$, a 43 amino acid peptide, is its ability to sequester actin monomers. Thanks to this ability, T $\beta 4$ plays a major role in cell migration and in multiple biological functions, including cell survival, cell protection from peroxide damage, angiogenesis, tissue repair, hair growth, and wound healing [38]. Interestingly, T $\beta 4$ is highly expressed in human newborns' saliva, but only scarcely in adults' saliva [39]. Immunohistochemical studies showed a high and disseminated expression of T $\beta 4$ in the normal liver [40] and liver tumors, including hepatocellular carcinoma [41]. T $\beta 4$ is highly expressed in the fetus, particularly in the fetal gut, pancreas, and liver, reinforcing the hypothesis of a major role for $\mathrm{T} \beta 4$ in developing the gastrointestinal tract [42]. T $\beta 4$ is also involved in human nephrogenesis, mainly expressed in the stromal-interstitial cells in the cortex and the fetal kidney's renal medulla [43].

A breakthrough in the project aimed to introduce $\mathrm{T} \beta 4$ in clinical practice is represented by the recent publication of an experimental study demonstrating the ability of thymosin $\mathrm{T} \beta 4$, when administered to pregnant mice, to stimulate fetal growth and organ development [44]. Newborns from pregnant mice treated with intraperitoneal T $\beta 4$ before preterm delivery showed the acceleration of lung, heart, and kidney development compared to control animals. Given that $\mathrm{T} \beta 4$ is a natural compound and not a drug, these preliminary experimental data represent a new base to start the proper trials for introducing the use of $\mathrm{T} \beta 4$ in clinical practice.

\section{Conclusions}

Unlike the "physiological" regenerative hypothesis, which indicated the postnatal period as the time for starting the regenerative approach, according to the recent experimental data, the trials could focus on the last weeks of pregnancy, with the administration of T $\beta 4$ in women with a programmed preterm delivery. This original regenerative approach aims to transform a newborn susceptible to developing chronic kidney or brain disease later in life, into a resistant subject, with positive consequences on the health system.

\section{Funding}

This research received no external funding.

\section{Acknowledgments}

Goce Kalcev (M.D.) participated in writing this paper in the framework of the International Ph.D. in Innovation Sciences and Technologies at the University of Cagliari, Italy.

\section{Conflicts of Interest}

The authors declare no conflict of interest.

\section{References}

1. Lu, J.; Wei, D.; Shen, S.; Xia, X.; He, J.; Sun, Y.; Lam, K.B.H.; Bao, W.; Xia, H.; Qiu, X. Increasing trends in incidence of preterm birth among 2.5 million newborns in Guangzhou, China, 2001 to 2016: an age-periodcohort analysis. BMC Public Health 2020, 20, 1653, https://doi.org/10.1186/s12889-020-09739-6.

2. Blencowe, H.; Cousens, S.; Chou, D.; Oestergaard, M.; Say, L.; Moller, A.-B.; Kinney, M.; Lawn, J.; the Born Too Soon Preterm Birth Action, G. Born Too Soon: The global epidemiology of 15 million preterm births. Reproductive Health 2013, 10, S2, https://doi.org/10.1186/1742-4755-10-S1-S2. 
3. Tommiska, V.; Lano, A.; Kleemola, P.; Klenberg, L.; Lehtonen, L.; Löppönen, T.; Olsen, P.; Tammela, O.; Fellman, V.; for the Finnish, E.C.S.G. Analysis of neurodevelopmental outcomes of preadolescents born with extremely low weight revealed impairments in multiple developmental domains despite absence of cognitive impairment. Health Science Reports 2020, 3, e180, https://doi.org/10.1002/hsr2.180.

4. van Hoorn, J.F.; Schoemaker, M.M.; Stuive, I.; Dijkstra, P.U.; Rodrigues Trigo Pereira, F.; van der Sluis, C.K.; Hadders-Algra, M. Risk factors in early life for developmental coordination disorder: a scoping review. Dev. Med. Child Neurol. 2020, 14781, https://doi.org/10.1111/dmcn.14781.

5. Roberts, D.; Brown, J.; Medley, N.; Dalziel, S.R. Antenatal corticosteroids for accelerating fetal lung maturation for women at risk of preterm birth. Cochrane Database Syst. Rev. 2017, https://doi.org/10.1002/14651858.CD004454.pub3.

6. Gould, J.B.; Bennett, M.V.; Phibbs, C.S.; Lee, H.C. Population Improvement Bias Observed in Estimates of the Impact of Antenatal Steroids to Outcomes in Preterm Birth. The Journal of Pediatrics 2020, https://doi.org/10.1016/j.jpeds.2020.11.067.

7. Schmidt, A.F.; Kannan, P.S.; Bridges, J.P.; Filuta, A.; Lipps, D.; Kemp, M.; Miller, L.A.; Kallapur, S.G.; Xu, Y.; Whitsett, J.A.; Jobe, A.H. Dosing and formulation of antenatal corticosteroids for fetal lung maturation and gene expression in rhesus macaques. Sci. Rep. 2019, 9, 9039, https://doi.org/10.1038/s41598-019-451716.

8. Bancalari, E. Antenatal Infections and Respiratory Outcome in Preterm Infants. Am. J. Perinatol. 2020, 37 , S39-S41, https://doi.org/10.1055/s-0040-1714347.

9. Faa, G.; Gerosa, C.; Fanni, D.; Monga, G.; Zaffanello, M.; Van Eyken, P.; Fanos, V. Morphogenesis and molecular mechanisms involved in human kidney development. J. Cell. Physiol. 2012, 227, 1257-1268, https://doi.org/10.1002/jcp.22985.

10. South, Andrew M.; Shaltout, Hossam A.; Washburn, Lisa K.; Hendricks, Alexa S.; Diz, Debra I.; Chappell, Mark C. Fetal programming and the angiotensin-(1-7) axis: a review of the experimental and clinical data. Clin. Sci. 2019, 133, 55-74, https://doi.org/10.1042/CS20171550.

11. Schumacher, M.; Liere, P.; Ghoumari, A. Progesterone and fetal-neonatal neuroprotection. Best Practice \& $\begin{array}{llllll}\text { Research Clinical Obstetrics \& } \quad \text { Gynaecology } & \text { 2020, } & \text { 69, }\end{array}$ https://doi.org/10.1016/j.bpobgyn.2020.09.001.

12. Fanni, D.; Fanos, V.; Monga, G.; Gerosa, C.; Locci, A.; Nemolato, S.; Van Eyken, P.; Faa, G. Expression of WT1 during normal human kidney development. The Journal of Maternal-Fetal \& Neonatal Medicine 2011, 24, 44-47, https://doi.org/10.3109/14767058.2011.606619.

13. Fanni, D.; Gerosa, C.; Van Eyken, P.; Gibo, Y.; Faa, G. Development of the human kidney: immunohistochemical findings. In Kidney Development in Renal Pathology, Springer: 2014; 29-41.

14. Siddiqui, A.; Chawla, D.; Kaur, J.; Mahajan, V.; Jain, S. Effect of fetal growth restriction on urinary podocalyxin levels at birth in preterm neonates. Pediatr. Res. 2020, https://doi.org/10.1038/s41390-0200987-2.

15. de Winter, D.; Salaets, T.; Gie, A.; Deprest, J.; Levtchenko, E.; Toelen, J. Glomerular developmental delay and proteinuria in the preterm neonatal rabbit. PLoS One 2020, 15, e0241384, https://doi.org/10.1371/journal.pone.0241384.

16. Faa, G.; Gerosa, C.; Fanni, D.; Nemolato, S.; Locci, A.; Cabras, T.; Marinelli, V.; Puddu, M.; Zaffanello, M.; Monga, G.; Fanos, V. Marked interindividual variability in renal maturation of preterm infants: lessons from autopsy. The Journal of Maternal-Fetal \& Neonatal Medicine 2010, 23, 129-133, https://doi.org/10.3109/14767058.2010.510646.

17. Lumbers, E.R.; Kandasamy, Y.; Delforce, S.J.; Boyce, A.C.; Gibson, K.J.; Pringle, K.G. Programming of Renal Development and Chronic Disease in Adult Life. Front. Physiol. 2020, 11, 757, https://doi.org/10.3389/fphys.2020.00757.

18. Fanos, V.; Gerosa, C.; Loddo, C.; Faa, G. State of the art on kidney development: how nephron endowment at birth can shape our susceptibility to renal dysfunction later in life. Am. J. Perinatol. 2019, 36, S33-S36, https://doi.org/10.1055/s-0039-1691798.

19. Luyckx, V.A.; Brenner, B.M. Clinical consequences of developmental programming of low nephron number. The Anatomical Record 2020, 303, 2613-2631, https://doi.org/10.1002/ar.24270.

20. Barron, T.; Kim, J.H. Preterm Birth Impedes Structural and Functional Development of Cerebellar Purkinje Cells in the Developing Baboon Cerebellum. Brain Sciences 2020, 10, https://doi.org/10.3390/brainsci10120897. 
21. Wu, Y.; Stoodley, C.; Brossard-Racine, M.; Kapse, K.; Vezina, G.; Murnick, J.; du Plessis, A.J.; Limperopoulos, C. Altered local cerebellar and brainstem development in preterm infants. NeuroImage 2020, 213, 116702, https://doi.org/10.1016/j.neuroimage.2020.116702.

22. Faa, G.; Marcialis, M.A.; Ravarino, A.; Piras, M.; Pintus, M.C.; Fanos, V. Fetal Programming of the Human Brain: Is there a Link with Insurgence of Neurodegenerative Disorders in Adulthood? Curr. Med. Chem. 2014, 21, 3854-3876, https://doi.org/10.2174/0929867321666140601163658.

23. Faa, G.; Manchia, M.; Pintus, R.; Gerosa, C.; Marcialis, M.A.; Fanos, V. Fetal programming of neuropsychiatric disorders. Birth Defects Res. C. Embryo Today Rev. 2016, 108, 207-223, https://doi.org/10.1002/bdrc.21139.

24. Fanni, D.; Gerosa, C.; Rais, M.; Ravarino, A.; Van Eyken, P.; Fanos, V.; Faa, G. The role of neuropathological markers in the interpretation of neuropsychiatric disorders: Focus on fetal and perinatal programming. Neurosci. Lett. 2018, 669, 75-82, https://doi.org/10.1016/j.neulet.2016.10.063.

25. Bourel-Ponchel, E.; Hasaerts, D.; Challamel, M.-J.; Lamblin, M.-D. Behavioral-state development and sleepstate differentiation during early ontogenesis. Neurophysiol. Clin. 2021, 51, 89-98, https://doi.org/10.1016/j.neucli.2020.10.003.

26. Butti, N.; Montirosso, R.; Giusti, L.; Borgatti, R.; Urgesi, C. Premature birth affects visual body representation and body schema in preterm children. Brain Cogn. 2020, 145, 105612, https://doi.org/10.1016/j.bandc.2020.105612.

27. Schmitz-Koep, B.; Bäuml, J.G.; Menegaux, A.; Nuttall, R.; Zimmermann, J.; Schneider, S.C.; Daamen, M.; Scheef, L.; Boecker, H.; Zimmer, C.; Gaser, C.; Wolke, D.; Bartmann, P.; Sorg, C.; Hedderich, D.M. Decreased cortical thickness mediates the relationship between premature birth and cognitive performance in adulthood. Hum. Brain Mapp. 2020, 41, 4952-4963, https://doi.org/10.1002/hbm.25172.

28. Kubo, K.-i.; Deguchi, K. Human neocortical development as a basis to understand mechanisms underlying neurodevelopmental disabilities in extremely preterm infants. J. Obstet. Gynaecol. Res. 2020, 46, 2242-2250, https://doi.org/10.1111/jog.14468.

29. Kochunov, P.; Huang, J.; Chen, S.; Li, Y.; Tan, S.; Fan, F.; Feng, W.; Wang, Y.; Rowland, L.M.; Savransky, A.; Du, X.; Chiappelli, J.; Chen, S.; Jahanshad, N.; Thompson, P.M.; Ryan, M.C.; Adhikari, B.; Sampath, H.; Cui, Y.; Wang, Z.; Yang, F.; Tan, Y.; Hong, L.E. White Matter in Schizophrenia Treatment Resistance. Am. J. Psychiatry 2019, 176, 829-838, https://doi.org/10.1176/appi.ajp.2019.18101212.

30. Nosarti, C.; Reichenberg, A.; Murray, R.M.; Cnattingius, S.; Lambe, M.P.; Yin, L.; MacCabe, J.; Rifkin, L.; Hultman, C.M. Preterm Birth and Psychiatric Disorders in Young Adult Life. Arch. Gen. Psychiatry 2012, 69, 610-617, https://doi.org/10.1001/archgenpsychiatry.2011.1374.

31. Fanni, D.; Gerosa, C.; Nemolato, S.; Mocci, C.; Pichiri, G.; Coni, P.; Congiu, T.; Piludu, M.; Piras, M.; Fraschini, M.; Zaffanello, M.; Iacovidou, N.; Van Eyken, P.; Monga, G.; Faa, G.; Fanos, V. "Physiological" renal regenerating medicine in VLBW preterm infants: could a dream come true? The Journal of MaternalFetal \& Neonatal Medicine 2012, 25, 41-48, https://doi.org/10.3109/14767058.2012.712339.

32. Faa, G.; Fanni, D.; Gerosa, C.; Fraschini, M.; Nemolato, S.; Ottonello, G.; Messana, I.; Cabras, T.; Monga, G.; Van Eyken, P. The subcapsular blue strip width: a new marker for evaluating the residual potential nephrogenesis in the newborn kidney. 2013; 387A-387A.

33. Bruschettini, M.; Romantsik, O.; Moreira, A.; Ley, D.; Thébaud, B. Stem cell-based interventions for the prevention of morbidity and mortality following hypoxic-ischaemic encephalopathy in newborn infants. Cochrane Database Syst. Rev. 2020, https://doi.org/10.1002/14651858.CD013202.pub2.

34. 34. Leijser, L.M.; de Vrie, L.S. Preterm brain injury: Germinal matrix-intraventricular hemorrhage and posthemorrhagic ventricular dilatation. Handb Clin Neurol 2019,162,173-199, https://doi.or/10.1016/B978-0444-64029-1.00008-4.

35. Philp, D.; Goldstein, A.L.; Kleinman, H.K. Thymosin $\beta 4$ promotes angiogenesis, wound healing, and hair follicle development. Mech. Ageing Dev. 2004, 125, 113-115, https://doi.org/10.1016/j.mad.2003.11.005.

36. Best, K. E.; Seaton, S. E.; Draper, E. S.; Field, D. J.; Kurinczuk, J. J.; Manktelow, B. N.; Smith, L. K. Assessing the deprivation gap in stillbirths and neonatal deaths by cause of death: a national population-based study. Archives of disease in childhood. Fetal and neonatal edition, 2019, 104(6), F624-F630, https://doi.org/10.1136/archdischild-2018-316124.

37. Goldstein, A.L.; Slater, F.D.; White, A. Preparation, assay, and partial purification of a thymic lymphocytopoietic factor (thymosin). Proceedings of the National Academy of Sciences 1966, 56, 1010, https://doi.org/10.1073/pnas.56.3.1010. 
38. Sosne, G.; Szliter, E.A.; Barrett, R.; Kernacki, K.A.; Kleinman, H.; Hazlett, L.D. Thymosin Beta 4 Promotes Corneal Wound Healing and Decreases Inflammation in Vivo Following Alkali Injury. Exp. Eye Res. 2002, 74, 293-299, https://doi.org/10.1006/exer.2001.1125.

39. Inzitari, R.; Cabras, T.; Pisano, E.; Fanali, C.; Manconi, B.; Scarano, E.; Fiorita, A.; Paludetti, G.; Manni, A.; Nemolato, S.; Faa, G.; Castagnola, M.; Messana, I. HPLC-ESI-MS analysis of oral human fluids reveals that gingival crevicular fluid is the main source of oral thymosins $\beta 4$ and $\beta 10$. J. Sep. Sci. 2009, 32, 57-63, https://doi.org/10.1002/jssc.200800496.

40. Nemolato, S.; Van Eyken, P.; Cabras, T.; Cau, F.; Fanari, M.U.; Locci, A.; Fanni, D.; Gerosa, C.; Messana, I.; Castagnola, M. Expression pattern of thymosin beta 4 in the adult human liver. European journal of histochemistry: EJH 2011, 55, https://doi.org/10.4081/ejh.2011.e25.

41. Theunissen, W.; Fanni, D.; Nemolato, S.; Di Felice, E.; Cabras, T.; Gerosa, C.; Van Eyken, P.; Messana, I.; Castagnola, M.; Faa, G. Thymosin beta 4 and thymosin beta 10 expression in hepatocellular carcinoma. Eur. J. Histochem. 2014, 58, 2242, https://doi.org/10.4081/ejh.2014.2242.

42. Nemolato, S.; Cabras, T.; Cau, F.; Fanari, M.U.; Fanni, D.; Manconi, B.; Messana, I.; Castagnola, M.; Faa, G. Different Thymosin Beta 4 Immunoreactivity in Foetal and Adult Gastrointestinal Tract. PLoS One 2010, 5, e9111, https://doi.org/10.1371/journal.pone.0009111.

43. Nemolato, S.; Cabras, T.; Messana, I.; Gerosa, C.; Faa, G.; Castagnola, M. Do $\beta$-Thymosins Play a Role in Human Nephrogenesis? In Kidney development in renal pathology, Springer: 2014; 81-93.

44. Faa, G.; Piras, M.; Mancuso, L.; Coni, P.; Pichiri, G.; Orrù, G.; Fanni, D.; Gerosa, C.; Cao, G.; Taibi, R.; Pavone, P.; Castagnola, M. Thymosin beta-4 prenatal administration improves fetal development and halts side effects due to preterm delivery. Eur. Rev. Med. Pharmacol. Sci. 2021, 25, 431-437, https://doi.org/10.26355/eurrev_202101_24411. 